\title{
Serotonin Transporter mRNA in Rat Brain Is Regulated by Classical Antidepressants
}

\author{
Juan F. López, Derek T. Chalmers, Delia M. Vázquez, Stanley J. Watson, and \\ Huda Akil
}

Key Words: Antidepressants, serotonin, mRNA, in situ hybridization

\section{Introduction}

Tricyclic antidepressants are believed to exert their therapeutic action by blocking the reuptake of catecholamines and serotonin (5-HT) from synaptic terminals (Fuller and Wong 1990). The reuptake of 5-HT is mediated by a specific 5-HT transporter localized in the presynaptic membrane (Briley 1985; Dawson and Wamsley 1983). The recent cloning of a complementary DNA (cDNA) for the rat 5-HT transporter (5-HTt) shows that this molecule has a 12 transmembrane domain similar to the gamma-aminobutyric acid (GABA), dopamine and norepinephrine transporters (Hoffman et al 1991). Studying the regulation of the 5-HTt is essential in understanding how antidepressants effect their therapeutic action and it may give us clues about the pathophysiology of disorders of serotonin regulation, such as Depression (Meltzer and Lowy 1987).

Most studies looking at 5-HTt function have been performed at the protein level. For example, it has been shown that antidepressants occupy the serotonin reuptake sites as measured by receptor binding (Kovachich et al 1988). Recent advances in molecular neurobiology have indicated that, in addition to protein synthesis, another important level of neuronal regulation occurs at the level of gene expression (mRNA) (Herman et al 1989). The recent elucidation of the 5-HTt messenger ribonucleic acid (mRNA) sequence allows us to study this molecule at the level of gene expression. In this study, we have investigated the effect of classical antidepressant administration on 5-HTt gene expression in rat brain by in situ hybridization histochemistry, a procedure that

From The Department of Psychiatry and The Mental Health Research Institute University of Michigan Medical Center, Ann Arbor, MI.

Address reprint requests to Juan F. Lopez, MD, Mental Health Research Institute, 205 Zina Pitcher Place, Ann Arbor, MI 48109.

Received January 12, 1993; revised October 25, 1993.

() 1994 Society of Biological Psychiatry allows us to quantify specific mRNA molecules in their neuroanatomical context (Watson et al 1987).

\section{Methods}

Male Sprague-Dawley adult rats ( $n=6$ per group) received daily intraperitoneal injections of saline $(0.9 \%)$, clorgyline $(4 \mathrm{mg} / \mathrm{kg})$, imipramine ( $10 \mathrm{mg} / \mathrm{kg}$ ) or amitriptyline $(10 \mathrm{mg} / \mathrm{kg})$ for 21 days. Rats were sacrificed $24 \mathrm{hr}$ after the last injection, brains were rapidly removed and frozen in liquid isopentane. Brains were sectioned on a cryostat $\left(-20^{\circ} \mathrm{C}\right)$ and thaw mounted onto polylysine-coated microscope slides. Tissue sections from the same level of the raphe nucleus in the brain stem were processed for in situ hybridization using previously published methods (Herman et al 1989; López et al 1992).

A segment of the 5-HTt cDNA was cloned from RNA extracted from rat brain stem, using the polymerase chain reaction technique (Saiki et al 1988) and ligated into a PGEM 32 piasmid. The complementary RNA (cRNA) probe obtained recognizes nucleotide sequences 772 to 1431 , a region that extends from the end of the third transmembrane domain to the beginning of the third extracytoplasmic loop. A $^{35}$ S labeled cRNA probe was synthesized and applied to the slides following procedures detailed elsewhere (Lopez et al 1992). The specificity of the probe was confirmed by hybridizing some sections with labelled "sense" mRNA probe and by treating other sections with $200 \mathrm{mg} / \mathrm{ml}$ of RNase prior to hybridization with the cRNA probe. In both cases, the resulting signal was equivalent to background. After hybridization, sections were washed, dried, and exposed to Kodak XAR-5 X-ray film at room temperature for 3 days. Later, sections were dipped in Kodak NTB-2 emulsion and stored desiccated in light tight boxes at $4^{\circ} \mathrm{C}$ for 10 days. The images obtained were quantified using a computerized image analysis system. Eight sections per animal were quantified and the mean value of the eight sections was assigned as

$0006-3223 / 94 / \$ 07.00$ 

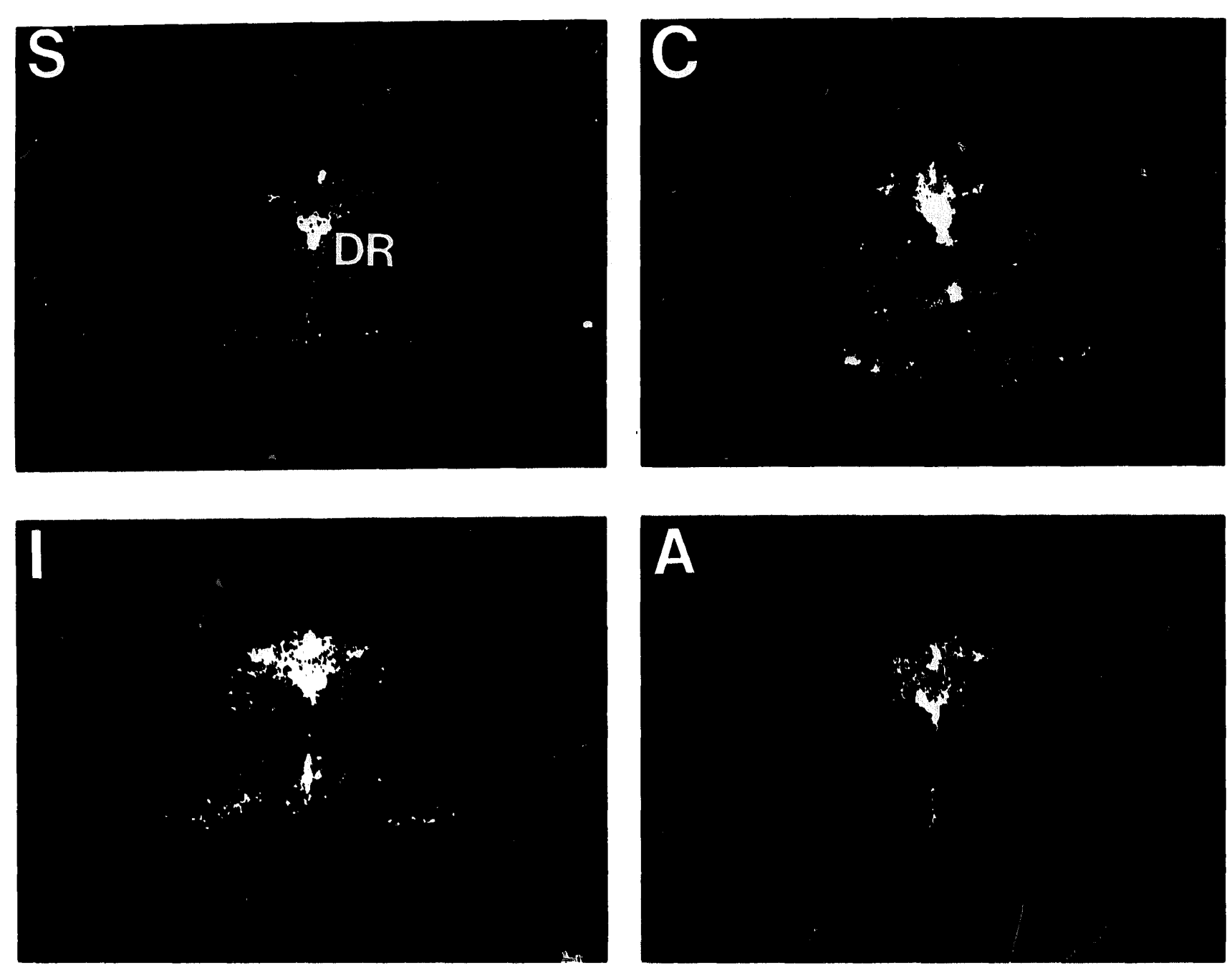

Figure 1. Serotonin transporter mRNA in the Dorsal Raphe nucleus of the rat detected by in situ hybridization. The four treatment groups are: saline (S), clorgyline (C), imipramine (I) and amitriptyline (A). DR = dorsal raphe nucleus

the value for each animal. Statistical analysis was performed by analysis of variance (ANOVA). Post hoc comparisons were made by using Fisher protected lenst-significant difference test.

\section{Results}

In situ hybridization revealed high levels of 5-HTt mRNA in the dorsal raphe nuclei of the upper brain stem (Figure 1). The median raphe nuclei also showed a positive mRNA signal, although less intense than the dorsal raphe. The dorsal raphe cells positive for the 5-HT transporter were localized more laterally and dorsally, whereas the median raphe cells were located along the midline. No other area in the mesencephalon showed evidence of 5-HTt mRNA containing neurons.

Quantification of the signal in the raphe nucleus revealed that the group of animals treated with clorgyline and with imipramine showed a significant increase in mRNA levels compared to the saline treated group $[F(3,20)=3.14, p<0.05]$. Animals treated with amitriptyline also showed an increase in mRNA levels that did not achieve statistical significance (Figure 2).

\section{Discussion}

The serotonin containing neurons in the raphe provide extensive innervation to several brain areas that are thought to be involved in the pathophysiology of affective disorders, such as the limbic system (Tork 1990). In situ hybridization allows us to study mRNA regulation in anatomically specific cell groups and offers a window to biosynthetic and regulatory events that occur in the neuronal cell body itself. Using a specific RNA probe, we have demonstrated that the 5-HTt gene is transcribed in the raphe, the brain area where serotonin cell bodies are localized. These serotonin cells synthesize the transporter, which is presumably transported through the axon to the synapses in the terminal fields.

Our study shows that chronic imipramine administration causes a significant increase in cransporter mRNA content, probably as a result of increased transcription. Binding studies looking at the serotonin transporter site in brain after antidepressant administration have been inconsistent. Some studies show an increase in uptake binding sites (Hrdina and Vu 1993), others show no changes (Marcusson and Ross 1990). It is possible that tricyclic 


\section{5-HT Transporter mRNA}

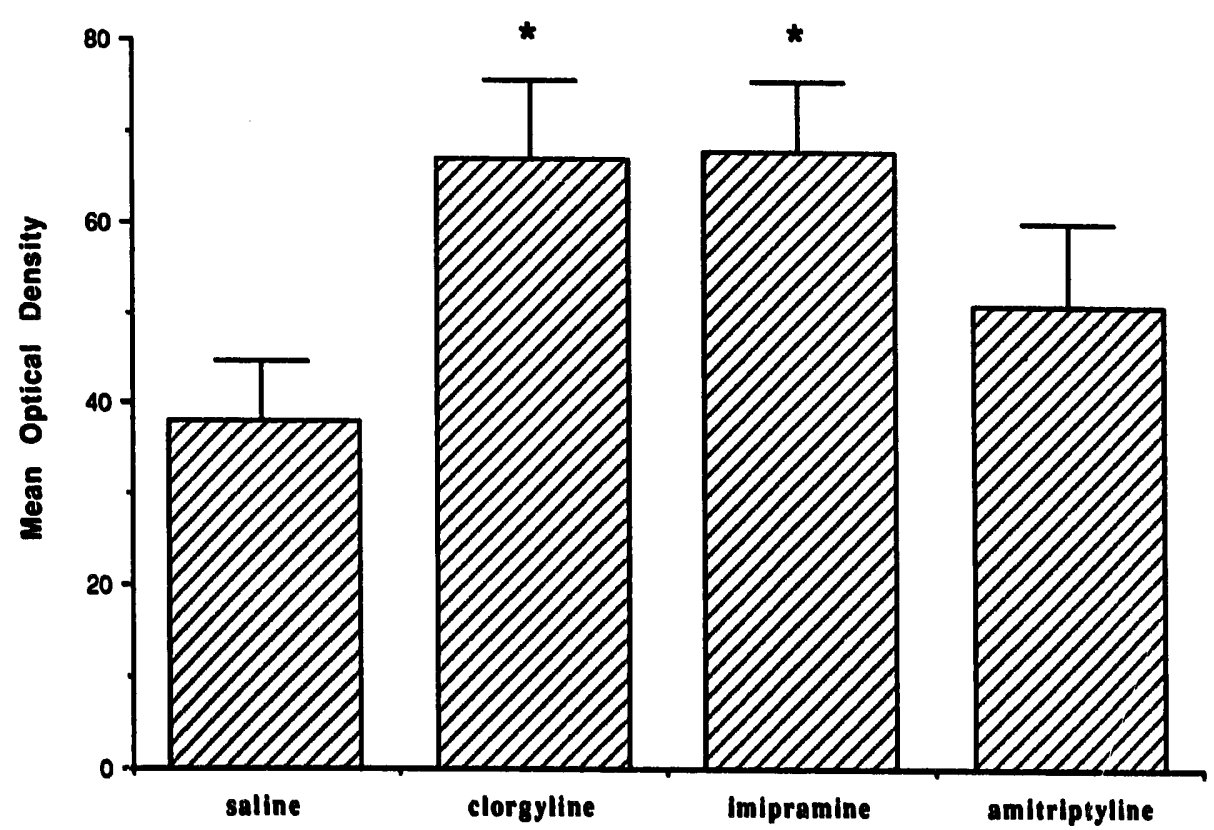

Figure 2. Results of 5-HT transporter mRNA quantification in the dorsal raphe. Values are expressed as relative optical density units. ${ }^{*}=$ values are significantly different from saline treated animals $(p<0.05)$

antidepressants, by occupying the serotonin transporter at the synapse, increase 5-HTt turnover and "signal" the raphe neurons to increase mRNA levels, which will eventually be translated into more transporter protein. Therefore, an increase in 5-HTt turnover may result in the same steady state levels of uptake binding sites and increased mRNA levels.

In our study, a surprising finding was that clorgyline, an MAO inhibitor, causes an increase in 5-HTt mRNA levels. It is possible that the MAOIs, by effectively increasing the levels of serotonin on the synapse, are also increasing the occupation of the transporter, again signaling to the serotonin cell that more protein needs to be synthesized. It appears therefore that increases in transporter gene expression may serve as an indication of increased serotonergic activity in the synapse, irrespective of whether this increase is

\section{References}

Briley M (1985): Imipramine binding: its relationship with serotonin uptake and depression. In Green AR (ed), Neuropharmacology of Serotonin. Oxford University Press, pp 50-78.

Dawson TM, Wamsley JF (1983): Autoradiographic localization of [3H] imipramine binding sites: Association with serotonergic neurons. Brain Res Bull 11:325-334.

Fuller RW, Wong DT (1990): Serotonin uptake and serotonin uptake inhibition. In Whitaker-Azmitia PM, Peroutka SJ (eds), The Neuropharmacology of Serotonin. New York: New York Academy of Sciences Vol 600, pp 68-78.

Herman JP, Schafer MHK, Sladek CD, Watson SJ (1989): Chronic electroconvulsive shock treatment elicits up-regulation of caused by blocking reuptake or by increasing synaptic 5-HT levels. Caution must be exercised, however, as changes in serotonin dynamics may also depend on the route and frequency of antidepressant administration. For example, a recent study reports that 5-HTt mRNA leveis may actually decrease after continuous chronic antidepressant administration using an osmotic minipump (Lesch et al 1993).

In conclusion, 5-HTt mRNA levels can be regulated by chronic antidepressant administration. This suggests that human postmortem studies of this molecule may be useful in investigating if regulation of the transporter is altered in depression. In addition, a knowledge of the cellular dynamics of the 5-HTt may provide keys in understanding what long-term effects antidepressants have on the serotonin neurons.

CRHI and AVP mRNA in select populations of neuroendocrine neurons. Brain Res 501:235-246.

Hoffman BJ, Mezey E, Brownstein MJ (1991): Cloning of a serotonin transporter affected by antidepressants. Science 254:579-580.

Hirdina PD, Vu TB (1993): Chronic fluoxetine treatment upregulates 5-HT uptake sites and 5-HT2 receptors in rat brain: An autoradiographic study. Synapse 14:324-331.

Kovachich GB, Aronson CE, Brunswick DJ, Frazer A (1988): Quantitative autoradiography of serotonin uptake sites in rat brain using [3H]cyanoimipramine. Brain Res 454:78-88. 
Lesch KP, Aulakh CS, Wolozin BL, Tolliver TJ, Hill JL, Murphy DL (1993): Regional brain expression of serotonin transporter mRNA and its regulation by reuptake inhibiting antidepressants. Mol Brain Res 17:31-35.

López JF, Palkovits M, Arat6 M, Mansour A, Akil H, Watson SJ (1992): Localization and quantification of Pro-opiomelanocortin mRNA and glucocorticoid receptor mRNA in pituitaries of suicide victims. Neuroendocrinology 56:491-501.

Marcuson JO, Ross SB (1990): Binding of some antidepressants to the 5-hydroxytryptamine transporter in brain and platelets. Psychopharmacology 102:145-155.

Melzer HY, Lowy MT (1987): The serotonin hypothesis of depression. In Melizer HY (ed), Psychopharmacology: The Third Generation of Progress. New York: Raven Press, pp 513-526.
Saiki RK, Gelfand DH, Stoeffel S, et al (1988): Primer-directed enzymatic amplification of DNA with a thermostable DNA polymerase. Science 239:487-491.

Törk I (1990): Anatomy of the serotonergic system. In WhitakerAzmitia PM, Peroutka SJ (eds), The Neuropharmacology of Serotonin. New York: New York Academy of Sciences Vol 600, pp 9-35.

Watson SJ, Sherman TG, Kelsey JE, Burke S, Akil H (1987): Anatomical localization of mRNA: In situ hybridization of neuropeptide systems. In Valentino K, Eberwine J, Barchas J (eds): In Situ Hybridization: Applications to Neurobiology. Oxford University Press, pp 50-78. 